five inch incision made between the ensiform and the um. bilicus. If the physician has the tact and takes the trouble to explain how very small the incision will be, that it will be neatly closed with white silk-untidy work on the dead is a desecration unworthy a physician-that all organs will be replaced if desired, that nothing but the abdominal wall will be cut when this can be promised, that the family will be welcome at the autopsy if this be practicable, as it sometimes will, and that the embalmer may do his work at the same time, then it will be found that many autopsies may be secured that are lost by neglecting to remove the belief that it is necessarily an extensive mutilation, leaving many visible marks. Where the brain is concerned a cleanly worker can promise that the incision will be entirely hidden by the hair and no evidence of the examination be noticeable. JAMES W. WALKER, M.D.

\section{A Universal Practitioner's License.}

Los Angeles, CaL., Sept. 4, 1903.

To the Editor:-In The Journal, August 29, p. 568, among the unsuccessful candidates in the Tennessee reports of registration, candidate 54, a graduate of the College of Physicians and Surgeons, Baltimore, class of 1876 , failed with a per cent. of 70. This fact substantiates the remarks of Dr. T. A. Borton in his article "The Turning Down of the Old Practitioner" published in ThE Journal, August 22, p. 505, with the exception that here the other unsuccessful candidates were nearly al recent graduates. Not knowing the questions asked and judging from the markings alone, I have nothing to say against this particular examining board; but I would like to have the following remarks reach those members of the profession who have more influence and power than has the average general practitioner. Something more is needed than a higher curriculum for the elevation of the profession, something that will make the American public respect the well learned doctor and not the well-to-do "Dock," as Dr. W. E. Quine classified them in one of his eloquent speeches. Any school with the best facilities and longest course in this country or abroad furnishes only the key to knowledge. Many of the best teachers in medicine to-day did not know the difference between an acid and an alkali at the time of their graduation years ago. The majority of successful practitioners, who were good students ten years ago, would not be able to pass a technical examination to-day with a higher per cent. than 60 , and I do not think it right to make the old practitioner suffer for the pre-existing laxity of the laws in any shape or manner, and all these different board examinations in the eyes of the public, prove to be a lack of self-confidence somewhere, by not recognizing the credentials of a reputable medical college from one state to another. The more privileges there are granted to improve the condition of the general practitioner, the more encouragement there will be for progressive study and investigation, and the fewer there will be of those who resort to quackery, criminal operations, fraudulent certificates and unethical conduct toward one another for the sake of the dollar. To remedy this, or at least the greater part of it, I beg to suggest the following rough sketch:

The American Medical Association shall elect one member in eaci state for the term of one year. These gentlemen shall constitute the Medical Council of the United States. Their aim shall be to elevate or to better the the the ture at least twice praction at least twice a year. At their frst convention they shall at once declare all those colleges which are now members in good standing in the Association of American Medical Colleges entitled to grant an interstate certificate to each of their graduates, after passing a satisfactory examination under the state board of examiners, in which the state member of the council shall act as chairman at the time of the examination, and on the same principles conducted now by the different boards. This interstate all over the Union, or, at least, in those states that will hold all over the Union, or, at least, in those states that will hold membership for reciprocity in the Medical Council at that time. to open their doors to the same candidates that passed the council's examination before their membership began

This council shall also issue an interstate certificate to every old practitioner in good standing and holding a state license who is a member of the United States Medical Council, without an is a member

ThIs council shall have judiciary. power to decide on questions time to time in the different states and relating to medical colleges, state board examinations. state medical societies and all other interests in the general welfare of the profession at large. The decision of the council in every case shall be final.

Considering the advance in surgery made by American surgeons, I am sure that foreign countries will seek reciprocity with the United States in the near future.

423 California Street.

S. B. LYoN, M.D.

\section{State Boards of Resistration.}

American Confederation of Reciprocating, Examining and Licensing Medical Boards.-A meeting of this body is called at the Southern Hotel, St. Louis, for October 27. An invitation is extended to all licensing boards to be represented at the meeting. The secretary of the confederation is Dr. B. $H$. Harison, Sault Ste. Marie, Mich.

Preliminary Examinations.-A committee of the Michigan State Board of Registration in Medicine met at Detroit to look into the work being done by the different medical colleges of that city. The cornmittee formulated a standard for the admission of students to the medical colleges of the state. The law requires that matriculants must at least be graduates of high schools having a classical course. Those who are not will have to pass an examination.

\section{Marriases.}

EMIL C. Becker, M.D., to Miss Ida Grace Beal, both of Chicago, September 16 .

Enward Hicks Hume, M.D., to Miss Lotta Carswell, both of Baltimore, September 24.

Louis P. Hamburger, M.D., to Miss Freda Cohn, both of Baltimore, September 20.

Henry Maynadier Fitzhugh, M.D., to Miss Mary Aldridge, both of Baltimore, September 23.

Adelbert H. Benson, M.D., Faxon, Okla., to Miss Ella M. Rahnapop of Chicago, September 23.

J. M. BrEDLER, M.D., Bridgewater, Va., to Miss Ina E. Long, Shenandoah County, Va., September 16.

Frederick Winliam Parker, M.D., to Miss Grace Elizabeth Peabody, both of Chicago, September 23.

Benjamin R. Parke, M.D., Wellsville, Ohio, to Miss Roberta Reynolds of Buffalo, N. Y., September 23.

Eugene Gates, M.D., Two Rivers, Wis., to Miss Gertrude Cordelia Marsh of Chicago, September 17.

Henry E. Haskins, M.D., Kingman, Kan., to Miss Bertha B. Knappenberger of Penalosa, Kan., September 20.

Daniel F. RoYer, M.D., Orange, Cal., to Mrs. Hettie Wilbur of Los Angeles, at Kingman, Ariz., September 16.

Arthur N. McKeever, M.D., Romney, W. Va., to Miss Katherine Keller, at Frostburg, Md., September 23.

Harvey Grant Beck, M.D., Baltimore, to Miss Katherine Elizabeth Clagett, at Blairsville, Pa., September 23.

Simon Flexner, M.D., New York City, to Miss Helen Whitall Thomas, at Bryn Mawr College, Pa., September 17.

William van Valzahi Hayes, M.D., New York City, to Miss Mary Coulbourne Conner of Altoona, Pa., September 9.

Meriweatier Lewis Anderson, M.D., of Albemarle County, Va., to Miss Annie Tatum, at Richmond, Va., September 23.

\section{Deaths.}

Calvin Skinner, M.D. Dartmouth Medical College, Hanover, N. H., 1841, surgeon of the One Hundred and Sixth New York Volunteers in the Civil War, some-time president of the Northern New York Medical Society and the Franklin County, N. Y., Medical Society, died at his home in Malone, N. Y., September 24, aged 85.

John M. Allen, M.D. University of Vermont, Burlington, 1890, a member of the American Medical Association, surgeon to Brightlook and St. Johnsbury hospitals, member of the Vermont State Medical Society, who was injured in an automobile accident, September 17, died at his home in St. Johnsbury, vt., September 18 . 